\title{
THE SIZE OF KELPS ON THE PACIFIC COAST OF NORTH AMERICA
}

\author{
T. C. Frye, G. B. Rigg, and W. C. Crandall
}

(WITH TWO FIGURES)

\section{Introduction}

The personal observations of the authors on the size of kelps have covered much of the west coast of North America from Cedros Island on the coast of Mexico to the Shumagin Islands on the coast of western Alaska.

The work of FRYE has been done during ten summers spent on Puget Sound, during several of which he has been director of the Puget Sound Marine Station at Friday Harbor, Washington, and one summer (I9I3) during which he was in charge of the expedition sent to southern Alaska by the United States Bureau of Soils for the purpose of investigating the kelps as a source of potash fertilizer. ${ }^{\mathrm{x}}$ The investigations of that summer included a careful examination of the coast from Dixon Entrance to Juneau (not including the west coast of Baranof Island), together with observations on kelps at a number of points along the coast of British Columbia where opportunity offered on the way to Alaska in May.

The observations of RIGG cover six summers in the Puget Sound region, portions of three of which were spent at the Puget Sound Marine Station, and portions of two of which were spent in making a survey of the kelp beds of the Puget Sound region for the United States Bureau of Soils as a part of its investigation of those kelps as a source of potash fertilizer. RIGG's Alaskan observations were made during the summer of 1913 when he was in charge of the United States Bureau of Soils expedition to western Alaska for the investigation of the kelps of that region as a source of potash

${ }^{x}$ All of the kelp investigation expeditions of which the writers of this paper were in charge were a part of the general investigation of the fertilizer resources of the United States conducted by Dr. Frank K. Cameron of the United States Bureau of Soils. 
fertilizer. A few incidental observations were made on kelps along the British Columbian coast and in southern Alaska on the way through that territory in May. Stops were made at Dixon Harbor, just north of Cape Spencer, and at Yakutat. No stop was made from Yakutat to Prince William Sound, but from this sound to the Shumagin Islands (including Cook Inlet and Kodiak Island) a reconnoissance survey was made. A careful examination of the coast was made at all points where conditions of weather and tides would permit.

The work of Crandall covers the coast from Cedros Island, Mexico, to Cape Flattery, Washington. It was done by him as biologist at the Scripps Institution for Biological Research and under appointments of the United States Bureau of Soils in I9I I, I9I2, and I9I3 to investigate the kelps of the region as a source of potash fertilizer.

The maximum size of kelps on the Pacific coast of North America has been a matter of interest ever since the beginning of botanical investigation in the region. Naturally a careful watch for large kelps was kept on these expeditions and frequent soundings in kelp beds were made. No specimens of Nereocystis or Macrocystis were found that at all approached in length the figures given for these species by the earlier writers. The figures that had been reported for the length of Alaria fistulosa were, however, practically corroborated, and the width of that species was found to be much greater than had been reported.

\section{Macrocystis}

Macrocystis pyrifera has been reported (without locality) by KJELlmaN (7) to reach a length of $200-300 \mathrm{~m}$. It has been reported by Firzroy (3) that it grew about the Falkland Islands in 30 fathoms of water, and by CAPTAIN COOK (I) that it grew at Kerguelen Island in 24 fathoms of water and that he feels warranted in saying that it reaches a length of 60 fathoms.

HARVEY quotes HoOKER as having calculated this species to reach a length of 700 feet $(213 \mathrm{~m}$.), and states that BORY St. VINCENT attributes to specimens a length of $I_{5} 00$ feet $(457 \mathrm{~m}$.). HowE (6) reports measurements of Macrocystis pyrifera and M. integrifolia 
from Peru. In regard to the size of the first species he quotes (p. 64) a field note of the collector (Dr. ROBERT COKER) as follows: "The largest piece measured 10 $\mathrm{m}$. and the entire single cluster weighed 30 lbs." He refers to the second species (p. 6r) as "the short plant $(2-3 \mathrm{~m}$. long) that grows gregariously on surf-swept rocks with densely intertangled rhizomatous holdfasts. ..." BURD (2) found Macrocystis plants varying in weight from 27 to 300 pounds. The largest specimen reported from the Puget Sound region is 40 feet in length (RIGG I2).

This species was not found growing in the territory covered by the western Alaskan expedition, but beds of it were found by the southeastern expedition. The deepest water in which it was found growing was $12.5 \mathrm{~m}$. Where the plants were growing in water of this depth, the longest portion of an attached plant floating at the surface was $13.8 \mathrm{~m}$. If this plant rose from the bottom at an angle of $45^{\circ}$, the under-water portion would be $17.3 \mathrm{~m}$. long, and the whole would be 31 . I m. It seems likely that it rarely if ever reaches a length of $38 \mathrm{~m}$. in Alaska.

The longest Macrocystis plant found on the Californian coast measured $45.7 \mathrm{~m}$. Many are only $9-13 \mathrm{~m}$. long. This species with a definite holdfast has been found by the writers growing in water varying in depth from $2 \frac{1}{2}$ to 14 fathoms. When it grows in shallower depths the holdfast is more like a rhizome. A single specimen of this plant has been found on the Californian coast that weighed ${ }_{1} 36 \mathrm{~kg}$. A specimen collected at Santa Barbara, California, was $23 \mathrm{~m}$. in length and weighed $22 \mathrm{~kg}$. Another one collected at the same place was $25 \mathrm{~m}$. long and weighed $37 \mathrm{~kg}$. The deepest sounding made in a Macrocystis bed was I 4 fathoms. This was on the Californian coast. The deepest sounding made in Alaska was 7 fathoms.

\section{Pelagophycus}

Pelagophycus porra has been found $45 \mathrm{~m}$. in length on the Californian coast (fig. I). It has not been found in the Puget Sound region or in Alaska. The deepest sounding made in Pelagophycus beds was 20 fathoms. BURD (2) found that these plants varied in weight from $\mathrm{I} 6$ to $7 \mathrm{I}$ pounds. 


\section{Nereocystis}

Statements of the length of Nereocystis luetkeana in various localities are shown in table I.

TABLE I

\begin{tabular}{|c|c|c|c|c|c|}
\hline Observer & Locality & Date & Depth reported & Meters & Part measured \\
\hline 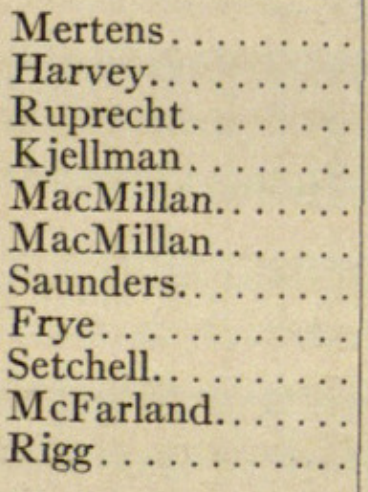 & $\begin{array}{l}\text { Alaska } \\
\text { Without locality } \\
\text { Alaska } \\
\text { Without locality } \\
\text { British Columbia } \\
\text { " } \\
\text { Alaska } \\
\text { Puget Sound } \\
\text { California } \\
\text { " } \\
\text { Puget Sound }\end{array}$ & $\begin{array}{l}1829 \\
1852 \\
1852 \\
1897 \\
1899 \\
1901 \\
1901 \\
1906 \\
1908 \\
1912 \\
1912\end{array}$ & $\begin{array}{l}45 \text { fathoms } \\
340 \text { feet } \\
250 \text { " } \\
\text { 100 m. } \\
80 \text { feet } \\
\text { 100 " } \\
70 \text { " } \\
21 \mathrm{~m} . \\
41 \text { " } \\
\text { 100 feet } \\
72 \text { " }\end{array}$ & $\begin{array}{r}82.3 \\
103.0 \\
76.2 \\
100.0 \\
24.4 \\
30.5 \\
21.3 \\
21.0 \\
41.0 \\
30.5 \\
21.9\end{array}$ & $\begin{array}{c}\text { Stipe only } \\
\text { Whole plant } \\
\text { " } \\
\text { " } \\
\text { " } \\
\text { " } \\
\text { " } \\
\text { " } \\
\text { " } \\
\text { " } \\
\text { " } \\
\text { " }\end{array}$ \\
\hline
\end{tabular}

SAUNDERS (15) thinks that Mertens' statement is "probably not true," since he (SAUNDERS) "has measured many fully developed plants on the California, Oregon, and Washington coasts, as well as on the Alaska coast, and has never found one exceeding the above figures" (70 feet). Frye (4) has indorsed SAunders' view. Setchell (r6) sees a possibility that the " 45 " in Mertens' statement is a "misprint . . . for $\mathrm{I}_{5}$, which, from all experience seems likely." He prefaces this, however, with the suggestion that Mertens' statement "must have been made with care, as are his statements in general." He also quotes RuprEcHT, who had found specimens 25 feet long on the Californian coast, but had added "that according to trustworthy natives in the employ of the N. A. Company at Fort Ross, it reaches a length ten times greater in the vicinity of Sitka and the Aleutian Islands." SETCHELL also says that in his observations from Kodiak Island, Alaska, to California he did not find any specimens that approached the dimensions reported by MERTENS and RUPRECHT, but adds "Off the entrance to Yakutat Bay, Alaska, while at anchor during a fog I saw soundings taken close to and among Nereocystis plants showing that the solid portions of the stipe were ro-12 fathoms in length. Altogether the plants thus observed must have been $45^{-50} \mathrm{~m}$. in length." SETCHELL's report of $4 \mathrm{r} \mathrm{m}$. above is based on a specimen 


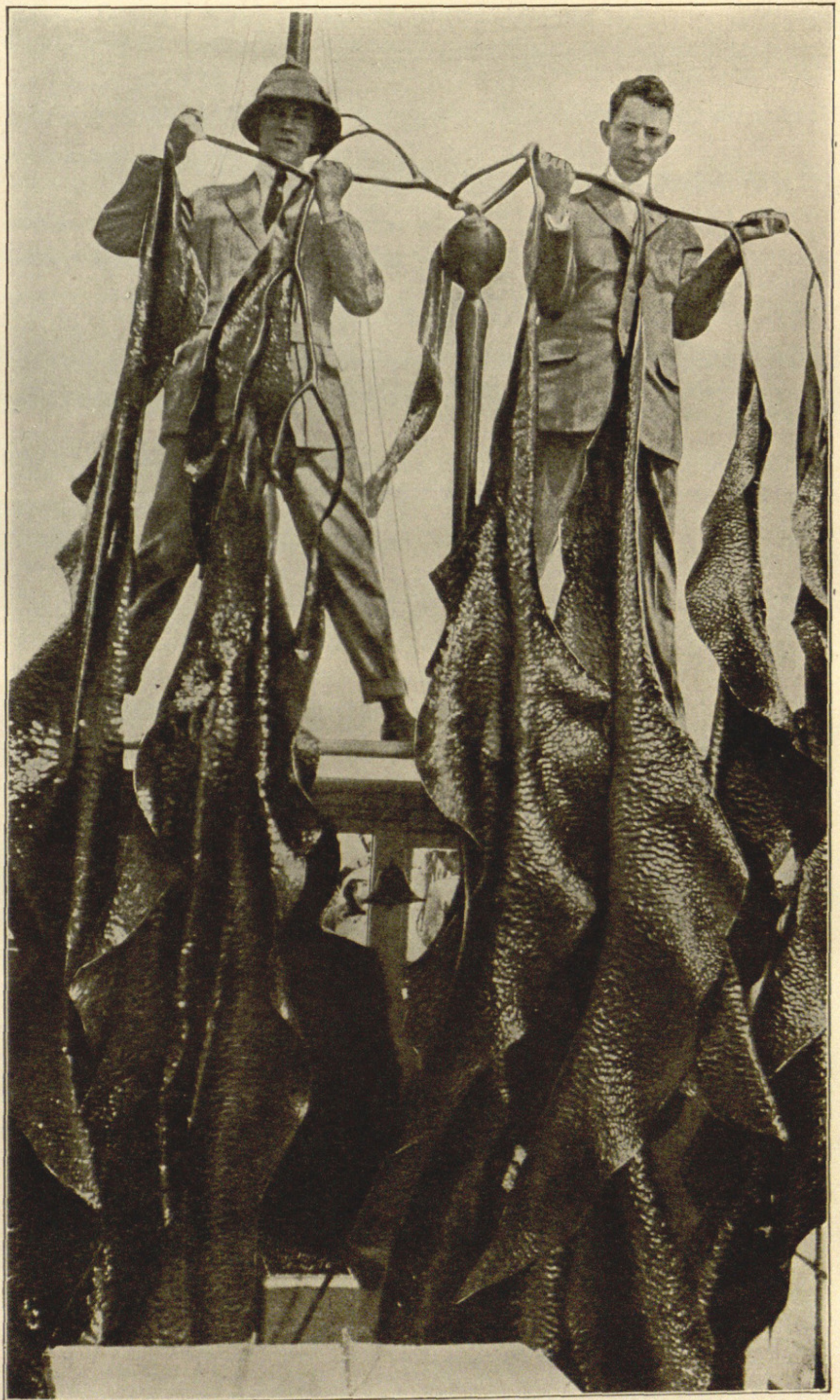

Fig. 1.-Pelagophycus porra, or elk kelp.-From Report no. roo, Bureau of Soils. 
that he paced at Carmel Bay, California. MacMillan (9) expresses the opinion that the length stated by KJELLMAN "is not at all excessive." McFarLand (8) says: "I have been unable to find individual plants of Nereocystis in the region examined by me which attained anything like the maximum dimensions given by Kjellman, Mertens, Setchell and Gardner, and MacMillan. Specimens up to roo feet in length are met with."

It should be noted that RUPRECHT's statement was based on mere hearsay. KJELLMAN (7) does not cite any measurements in support of his statement. Mertens' (II) statement has never been confirmed by measurements. There is practical agreement in the statements by SAUnders (15), Frye (4), and RigG (12, 13). Longer kelps than those found by the last three observers were reported by MacMillan (io), Setchell (i6), and McFarLand (8).

Not a single specimen has ever been found by the writers of this paper that reached $40 \mathrm{~m}$. in length, nor has any evidence been obtained by them from soundings that plants reach this length in any of the beds examined. The largest specimen of Nereocystis measured on the southern Alaskan expedition was $20.7 \mathrm{~m}$. This was at Point Davidson on Annette Island. The longest specimen of this species measured on the western Alaskan expedition was $18.9 \mathrm{~m}$. This was at Resurrection Bay on the Kenai Peninsula. Many statements were made to the writers about extremely large kelps, but when the beds were visited, these large specimens could not be found. The longest lamina found by our expeditions is $780 \mathrm{~cm}$. The greatest width of lamina found is $20 \mathrm{~cm}$. The length of a pneumatocyst found at Yakutat was $462 \mathrm{~cm}$. All measurements of kelps at Yakutat were from drift specimens. None were seen growing. The region was visited in May, which is too early for the new crop of kelp there. The maximum circumference of bulbs measured on our expeditions is $453 \mathrm{~mm}$. This specimen was found at Danger Bay on Afognak Island. Other bulb circumferences measured were $425 \mathrm{~mm}$. at Meares Passage, $367 \mathrm{~mm}$. at Yakutat, $365 \mathrm{~mm}$. at Sand Point, and $350 \mathrm{~mm}$. at Resurrection Bay.

MCFARLAND (8) has found the weight of fresh Nereocystis plants on the Californian coast to vary from 43 to 76 pounds. BURD 
found a maximum weight of $5^{6}$ pounds at the season at which the sample was taken (fall). One of us (RIGG I2, I3) has found the weight of the fronds and pneumatocyst to be $18-35$ pounds on Puget Sound. The maximum weight found by our expeditions in Alaska was $55 \mathrm{~kg}$. This included the fronds and $210 \mathrm{~cm}$. of the pneumatocyst. The fronds alone weighed $49 \mathrm{~kg}$. This specimen was collected at Resurrection Bay. The same portions of specimens collected at other points weighed as follows: Smith Island, $24 \mathrm{~kg}$.; Sand Point, $16 \mathrm{~kg}$. The slender portion of a stipe collected near Seattle, Washington, was found by the writers to weigh $87 \mathrm{gm}$. per meter. A similar piece collected at Sand Point, Alaska, weighed $227 \mathrm{gm}$. per meter. A holdfast at Sand Point weighed $3.4 \mathrm{~kg}$.

A summary of the measurements of the largest Nereocystis plants found by the writers is given in table II.

\section{TABLE II}

\begin{tabular}{|c|c|c|c|c|}
\hline Locality & $\begin{array}{l}\text { Total length } \\
(\mathrm{m} .)\end{array}$ & $\begin{array}{l}\text { Length of } \\
\text { fronds (m.) }\end{array}$ & $\begin{array}{l}\text { Diameter of } \\
\text { bulb (mm.) }\end{array}$ & $\begin{array}{l}\text { Weight of } \\
\text { plant (kg.) }\end{array}$ \\
\hline 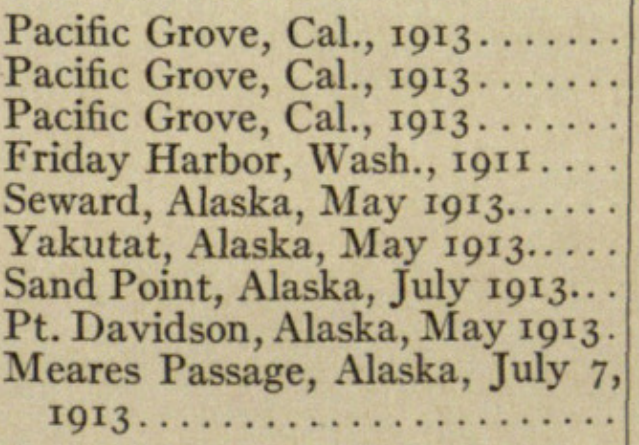 & $\begin{array}{l}34 \cdot 7 \\
36 \cdot 5 \\
38 \cdot 4 \\
21 \cdot 9 \\
19 \cdot 0 \\
13 \cdot 7 \\
20.6 \\
21.2\end{array}$ & $\begin{array}{c}\text { 1. } \\
3.6 \\
1.8 \\
\ldots \ldots \ldots \\
7.9 \\
\ldots \ldots \ldots \\
3.3 \\
5.4\end{array}$ & \begin{aligned} \multicolumn{1}{c}{93} \\
137 \\
100 \\
$\ldots \ldots \ldots \ldots \\
116 \\
120.5 \\
113.0 \\
\ldots \ldots \ldots \ldots\end{aligned}$ & $\begin{array}{r}7.0 \\
13.6 \\
7.5 \\
\ldots \ldots \ldots \\
55.4 \\
\ldots \ldots . . \\
16.2 \\
\ldots \ldots \ldots \ldots\end{array}$ \\
\hline
\end{tabular}

The following soundings include the deepest ones made by the writers in beds of Nereocystis: Resurrection Bay, Alaska, 5 fathoms; Kodiak Island, Alaska, 6 fathoms; Danger Bay, Alaska, 6.5 fathoms; Pacific Grove, California, 9 fathoms.

\section{Alaria}

The other kelp forming large beds in Alaska is Alaria fistulosa (fig. 2). The maximum width mentioned by SETCHELl and GARDNER ( 17 ) is $\mathrm{Im}$. and the maximum length is $25 \mathrm{~m}$. The number of sporophylls is given at about 200 . 


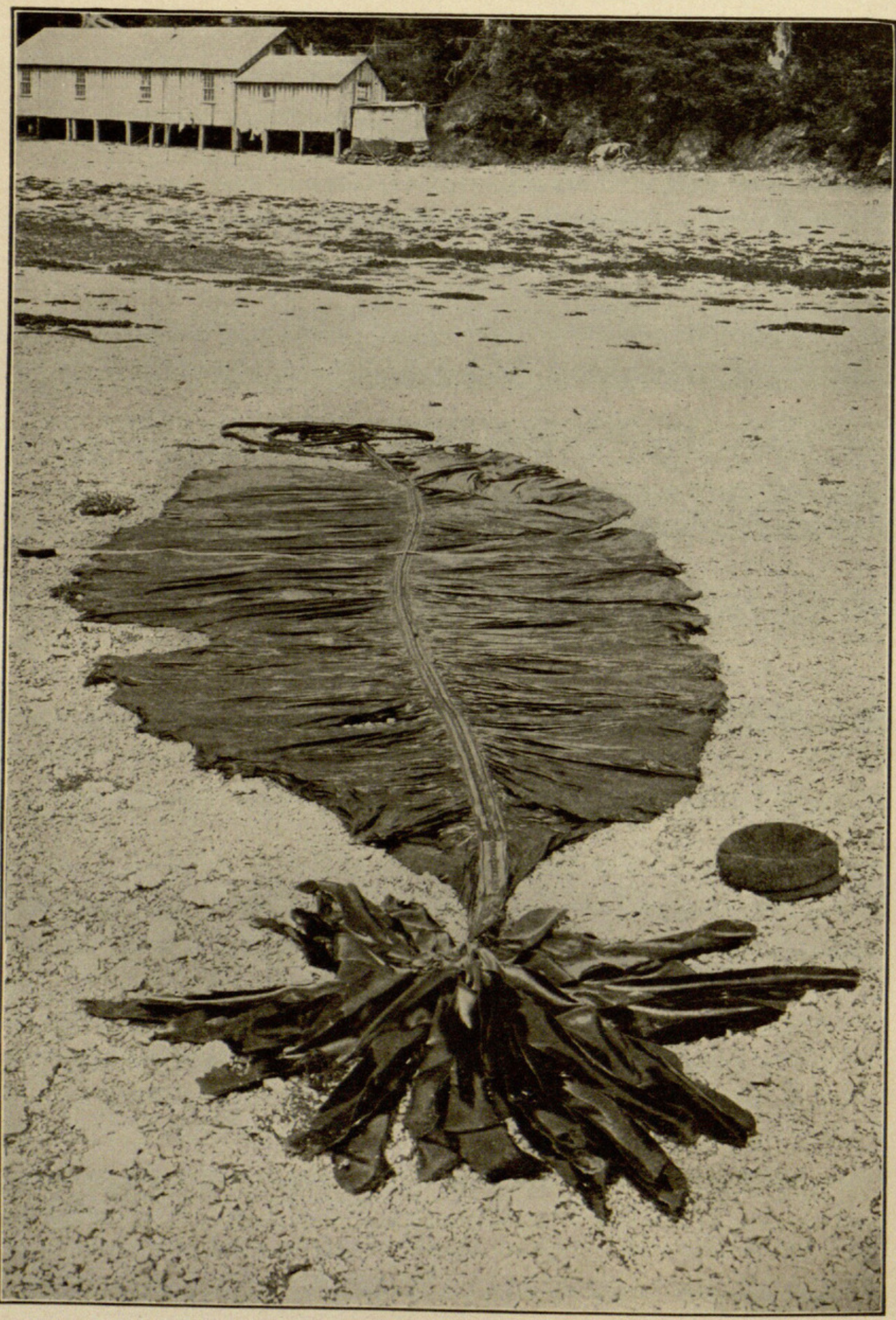

Fic. 2.-Alaria fistulosa: general appearance of a wide-leaved plant.-From Report no. roo, Bureau of Soils. 
Specimens collected by Griggs and Rigg at Anchor Point, Cook Inlet, measured as follows: length $\mathrm{I} 3 \mathrm{~m}$., $21 \mathrm{~m} ., 22 \mathrm{~m}$., I8 m.; width $232 \mathrm{~cm}$., I $75 \mathrm{~cm}$., $170 \mathrm{~cm}$., I $23 \mathrm{~cm}$., respectively. The first of these specimens had 220 sporophylls, the largest of which measured $65 \mathrm{~cm}$. in length and $84 \mathrm{~mm}$. in width. The width of the midrib was $53 \mathrm{~mm}$.

All of these plants were badly frayed at the tip, a great deal of material evidently having been worn off by the violence of the tidal currents. Regeneration from the base seems to be continuous throughout the life of the individual in this species. It is thus impossible to say whether these specimens had at any time been longer than they were when collected.

The weights found by our expeditions for portions of the fronds of Alaria fistulosa of the sizes given are shown in table III.

TABLE III

\begin{tabular}{|c|c|c|c|c|}
\hline \multicolumn{2}{|r|}{ Locality } & Length (m.) & Width (cm.) & Weight (kg.) \\
\hline$\underset{*}{\text { Cook Inlet, }}$ & $\underset{*}{\operatorname{Alaska} \ldots \ldots \ldots \ldots \ldots \ldots \ldots \ldots}$ & $\begin{array}{l}19.0 \\
18.5\end{array}$ & $\begin{array}{l}170 \\
175\end{array}$ & $\begin{array}{l}8.1 \\
9.8\end{array}$ \\
\hline Red Bay, & " $\ldots \ldots \ldots \ldots \ldots$ & 19.0 & I35 & ..... \\
\hline Cook Inlet, & $" \quad \ldots \ldots \ldots \ldots \ldots \ldots$ & 14.0 & 132 & $7 \cdot 1$ \\
\hline Kodiak Island, & $" \quad \ldots \ldots \ldots \ldots \ldots \ldots$ & I 5.0 & 25 & 0.9 \\
\hline
\end{tabular}

The deepest sounding made in an Alaria bed was 5 fathoms (Middle Islands, Alaska).

\section{Summary}

I. The observations of the writers do not tend to confirm the earlier statements of the great length of Nereocystis and Macrocystis.

2. Their observations on Alaria fistulosa confirm earlier statements of its length. Its maximum width was found to be more than twice as great as reported in literature that has come to the attention of the writers.

\section{University of Washington, Seattle, AND}

The Scripps Institution for BIOLOgical Research 


\section{LITERATURE CITED}

I. Cook, Captain, Report of second voyage.

2. Burd, J. S., Univ. Calif. Publ., Bull. 248, Coll. Agric. I9I5.

3. Fitzroy, R., Voyages of the Adventure and Beagle 2:246-247. 1836 .

4. Frye, T. C., Nereocystis luetkeana. Bot. Gaz. 42:142-146. I9o6.

5. Harvey, W. H., Nereis Boreali Americana. Part I. p. 82. Smithsonian Institution. $185^{2}$.

6. Howe, Marshall A., The marine algae of Peru. Mem. Torr. Bot. Club 15:I9I4.

7. KJellman, F. R., Laminariaceae. Engler und Prantl, Die Natürlichen Pflanzenfamilien $\mathbf{r}^{2}$ : 1897 .

8. McFarLand, F. M., Kelps of the central California coast. Senate Doc. I90: $194-208$. I9I2.

9. MacMillan, C., Observations on Nereocystis. Bull. Torr. Bot. Club 26:273. 1899 .

10. - The kelps of Juan de Fuca. Postelsia 193-220. I90I.

II. Mertens, Henry, Linnaea 4: I829.

12. RIGG, G. B., Ecological and economic notes on Puget Sound kelps. Senate Doc. 190:179-193. I9I2.

13. - Ecological and economic notes on Nereocystis luetkeana. Plant World 15 $_{5}: 83-92$. I9I2.

14. Ruprecht, F. J., Neue oder unbek. Pfl. a. d. Nordl. Th. des stillen Oceans. 1852.

15. Saunders, De A., Harriman Alaska Exp., The algae. Proc. Wash. Acad. Sci. 3:39I-486. I90I.

r6. Setchell, W. A., Nereocystis and Pelagophycus. Bot. Gaz. 45:125-134. I908.

17. Setchell, W. A., and Gardner, N. L., Algae of northwest America. Univ. Calif. Publ. Bot. $1: 165-418$. I913. 


\section{$2 \mathrm{BHL}$ Biodiversity Heritage Library}

Frye, Theodore C., Rigg, George B., and Crandall, W C . 1915. "The Size of Kelps on the Pacific Coast of North America." Botanical gazette 60(6), 473-482. https://doi.org/10.1086/331689.

View This Item Online: https://www.biodiversitylibrary.org/item/108949

DOI: https://doi.org/10.1086/331689

Permalink: https://www.biodiversitylibrary.org/partpdf/223717

\section{Holding Institution}

Missouri Botanical Garden, Peter H. Raven Library

\section{Sponsored by}

Missouri Botanical Garden

\section{Copyright \& Reuse}

Copyright Status: Public domain. The BHL considers that this work is no longer under copyright protection.

This document was created from content at the Biodiversity Heritage Library, the world's largest open access digital library for biodiversity literature and archives. Visit BHL at https://www.biodiversitylibrary.org. 